\title{
Biogas production from wheat straw: community structure of cellulose-degrading bacteria
}

\author{
Li Sun, Bettina Müller and Anna Schnürer
}

\begin{abstract}
Background: Wheat straw is one of the most abundant crop residues produced in the world, making it highly interesting as a substrate for biogas production. However, due to the complex structure, its degradability and gas yield are low. The degradability can be improved by pre-treatment, making the material more accessible to microbial degradation.

Methods: To investigate the microbial response to straw as a feed stock for biogas production, this study examined the community structure of cellulose-degrading bacteria in lab-scale biogas digesters operating with manure, alone or in co-digestion with straw, with and without pre-treatment (steam-explosion) at different temperatures. The community was studied by targeting the functional gene encoding glycoside hydrolases of families 5 and 48 using T-RFLP, clone libraries and GPCR.
\end{abstract}

Results: In general, bacteria belonging to the phyla Firmicutes and Bacteroidetes dominated the cellulose-degrading bacteria community in all digesters. The degree of similarity to the characterised bacteria was often low, and some clones were more closely related to the uncultured bacteria. The addition of straw, pre-treatment of straw and increasing operating temperature all affected the cellulose-degrading community structure, with differing responses in the cel48 and cel5 communities. Both communities changed in response to temperature, while only the cel5 community was affected by the addition of straw and cel48 community by straw pre-treatment.

Conclusions: The addition of straw, pre-treatment of straw and operating temperature all affected the cellulosedegrading community in biogas digesters, but there were no major differences in the digester performance and gas yield.

Keywords: Biogas; Cellulose; Community structure; Temperature; Glycoside hydrolases; Cel48; Cel5

\section{Background}

Emission of greenhouse gases (e.g. the fossil fuel-derived $\mathrm{CO}_{2}$ ) has become a global concern, but about $88 \%$ of global energy consumption still derives from fossil fuels [1]. To meet the environmental challenges, the EU member states have decided to increase the proportion of renewable energy up to $20 \%$ of total consumption by 2020 [2]. Anaerobic digestion (AD) is highly interesting in this context, as it can function in waste treatment, production of a renewable energy carrier (biogas) and production of an organic fertiliser [3]. Various kinds of organic materials can be used as substrates for biogas production, such as sewage sludge, manure, organic

\footnotetext{
* Correspondence: Anna.Schnurer@slu.se

Department of Microbiology, Uppsala Biocenter, Swedish University of Agricultural Sciences, Box 7025, 75007 Uppsala, Sweden
}

municipal waste and agricultural wastes [4]. Among the agricultural wastes, straw is an interesting feedstock for biogas production [3]. For example, wheat straw is the most abundant crop residue in Europe and second most abundant in the world [5]. However, the character and composition of straw, with cellulose fibres intertwined with hemicelluloses and lignin, make it difficult to degrade [6]. Moreover, the use of straw for biogas production is restricted by its high $\mathrm{C} / \mathrm{N}$ ratio and low levels of trace elements, limiting microbial growth and activity. The biogas yield from straw can be increased by pretreatment, making the material more accessible to microbial degradation [3,6,7]. Furthermore, by co-digestion with more nitrogen-rich materials, for example, animal manure or food waste, the nutrient limitation can be overcome [8-11]. 
The microbial degradation of organic material to biogas consists of four steps: (1) hydrolysis of complex organic polymers to soluble compounds; (2) fermentation of the products of hydrolysis into intermediate compounds such as fatty acids and alcohols; (3) anaerobic oxidation of these intermediate products to produce acetate, $\mathrm{H}_{2}$ and $\mathrm{CO}_{2}$; and (4) methane production by methanogenic Archaea [12]. In the case of straw, it has been suggested that the crystalline structure of the lignocelluloses obstructs degradation in the initial step and thus the hydrolysis of these insoluble compounds becomes the rate-limiting step $[13,14]$. Numerous studies have examined anaerobic cellulosedegrading bacteria and their enzymatic capabilities in order to clarify the degradation mechanisms and identify ways to enhance degradation rates. However, most of these studies have been performed on samples from gut and soil ecosystems $[3,13,15,16]$ and only a few have examined cellulose-degrading bacteria in biogas digesters [17-19].

In general, anaerobic degradation of cellulose can be performed by physiologically diverse taxa of microorganisms $[3,13,20]$. The degradation proceeds through the action of different cellulases, such as endoglucanases, exoglucanases and $\beta$-glucosidases, together with different enzymes attacking hemicellulose $[3,13,21]$. The enzymes can either be soluble or, as in the anaerobic bacteria, combined in cell-bound cellulosomes $[3,13]$. The glycoside hydrolases are grouped into 120 amino acid sequence-based families according to the international classification of carbohydrate-active enzymes (CAZy database). In anaerobic bacteria, the cellulosedegrading glycoside hydrolases are mainly allocated to the glycoside hydrolase families 5, 9 and 48 [22-24]. Recently, Pereyra et al. in 2010 [24] designed and validated consensus degenerated primers to amplify the glycoside hydrolase genes of families cel5 and cel48 with the aim of enabling the characterisation and quantification of cellulose-degrading bacteria in biogas digesters.

The aim of the present study was to provide further knowledge about cellulose-degrading bacteria in biogas processes. Specific objectives were to examine the response in the community of bacteria to the addition of straw, non-treated and pre-treated by steam explosion, and to investigate the effect on the community by a change in operating temperature from mesophilic to thermophilic. The microbial community structure and the abundance of anaerobic cellulose-degrading bacteria were studied by targeting the functional gene encoding the glycoside hydrolases of families 5 and 48 [24] and by performing terminal-restriction fragment length polymorphism (T-RFLP), clone libraries and quantitative polymerase chain reaction (qPCR).

\section{Methods}

\section{Digester samples}

The samples used for the community analysis originated from four laboratory-scale anaerobic reactors (RM, RS, $R^{T c} S S$ and $R^{37} S S$ ), operating semi-continuously and fed 6 days per week for a total of 455 days [25]. All digesters were started at mesophilic temperature $\left(37^{\circ} \mathrm{C}\right)$ and operated with an organic loading rate of $2.8 \mathrm{~g} \mathrm{VS} \mathrm{L}^{-1}$ day $^{-1}$ and a hydraulic retention time (HRT) of 25 days. Digester RM processed cow manure as the only substrate during the whole period of operation, while digester RS operated with mechanical chopped (un-treated) straw and cow manure [25]. Digesters $\mathrm{R}^{\mathrm{Tc}} \mathrm{SS}$ and $\mathrm{R}^{37} \mathrm{SS}$ were fed with the same substrate, processed steam-exploded straw [22\% of total volatile solids (VS)] and cow manure ( $78 \%$ of total VS), and were initially run at $37^{\circ} \mathrm{C}$. Digester $\mathrm{R}^{\mathrm{Tc}} \mathrm{SS}$ was then operated under the same conditions for the whole experimental period, while digester $\mathrm{R}^{37} \mathrm{SS}$ was subjected to a temperature rise from day 90 . At first the temperature was raised (by approximately $1^{\circ} \mathrm{C} /$ week) to reach an operating temperature of $44^{\circ} \mathrm{C}$ on day 140 . The digester, now called $\mathrm{R}^{44} \mathrm{SS}$, was then operated with these conditions at approximately 3 HRT. On day 226 the temperature was raised again (by approximately $1^{\circ} \mathrm{C} /$ week) to reach $52^{\circ} \mathrm{C}$ in the digester, now called $R^{52} \mathrm{SS}$, on day 299 [25]. Again, the digesters were operated at around 3 HRT to ensure wash-out of the non-active microbial population. The methane yields were similar in all digesters (0.13 to $\left.0.17 \mathrm{~N} \mathrm{~L} \mathrm{CH}_{4} / \mathrm{kg} \mathrm{VS}\right)$, with no increase in response to straw addition, steam-explosion treatment or temperature change [25].

\section{DNA extraction}

Samples $(20 \mathrm{~mL})$ were withdrawn from each digester after operation at approximately 3 HRT under different management conditions and stored at $-20^{\circ} \mathrm{C}$. For digesters $R^{37} S S, R^{44} S S$ and $R^{52} S S$, samples were taken on days 89,224 and 402 , corresponding to the operating temperatures of $37^{\circ} \mathrm{C}, 44^{\circ} \mathrm{C}$ and $52^{\circ} \mathrm{C}$. Digester $\mathrm{R}^{\mathrm{Tc}} \mathrm{SS}$, which operated at $37^{\circ} \mathrm{C}$ for the whole period, was sampled after the same period of operation, i.e. days 89, 224 and 402 , and these samples were named $\mathrm{R}^{\mathrm{Tc}} \mathrm{SS}, \mathrm{S} 1$ to $\mathrm{S} 3$. Total genomic DNA was extracted from triplicate samples using the method described by Westerholm et al. [26]. Aliquots of $200 \mu \mathrm{L}$ digester sludge were used for the DNA extraction, and $60 \mu \mathrm{L}$ water was used in the final elution of DNA.

\section{PCR amplification, cloning and sequence analysis}

Primers targeting the glycoside hydrolase families 5 (cel5_392F: 3'-GAG CAT GGG CTG GAA YHT NGG NAA-5' and cel5_754R: 3'-CAT CAT AAT CTT TGA AGT GGT TTG CAA TYT GDK TCC A-5') and 48 (cel48_490F: 3' '-TNA TGG TTG AAG CTC CDG AYT 
AYG G-5' and cel48_920R: 3'-CCA AAN CCR TAC CAG TTR TCA ACR TC-5') were used to study the cellulose-degrading bacterial community structure [24]. Polymerase chain reaction (PCR) amplification was performed with Maxima Hot Start PCR Master Mix (Fermentas, Thermo Fisher Scientific, Hudson, NH, USA) using the following programme: initial denaturation at $95^{\circ} \mathrm{C}$ for $5 \mathrm{~min}, 40$ or 60 cycles of denaturation at $95^{\circ} \mathrm{C}$ for $45 \mathrm{~s}$, annealing at $51^{\circ} \mathrm{C}$ (cel5, 60 cycles) or $56^{\circ} \mathrm{C}$ (cel48, 40 cycles) for $45 \mathrm{~s}$ and elongation at $72^{\circ} \mathrm{C}$ for $45 \mathrm{~s}$, followed by a final extension step of $7 \mathrm{~min}$ at $72^{\circ} \mathrm{C}$. Triplicate extractions of DNA were diluted 10,20 , 50 and 100 -fold and subsequently used as templates to find the optimal dilution to reduce inhibition during the PCR. For the optimal dilution, triplicate PCR runs were conducted for each sample. The resulting products from nine PCR reactions were pooled and purified with QIAquick gel extraction kit (Qiagen, Hilden, Germany) to reduce the potential bias. Clone libraries were constructed for the cel5 community with samples from $\mathrm{R}^{44} \mathrm{SS}$ and for the cel48 community using samples from $R M, R^{37} S S$ and $R^{44} S S$ by ligation of the gel-purified PCR amplicon into $\mathrm{pCR}^{\mathrm{m}} 4$ - $\mathrm{TOPO}^{\circ}$ vector (Invitrogen Life Technologies, Grand Island, NY, USA), followed by transformation of the ligation product into TOP10 One Shot ${ }^{\circ}$ chemically competent Escherichia coli (Invitrogen), according to the manufacturer's instructions. The sequences obtained were quality-checked and edited with the software package Geneious, version 5.6.5 (Biomatters Ltd., Auckland, New Zealand) and subsequently assigned to operational taxonomic units (OTU). The sequences were compared with sequences available in the NCBI GenBank. Alignment of cloned sequences and selected reference sequences, as well as sequences from uncultured bacteria, was conducted using the programme MUSCLE [27]. The phylogenetic trees were constructed with the MEGA programme version 5 using the maximum likelihood method and WAG model [28]. The confidence of the trees was tested by bootstrap resampling analysis for 1,000 replicates.

\section{T-RFLP}

Both cel5 and cel 48 genes were amplified, using the PCR conditions described above. The $5^{\prime}$ ends of the primers cel5_754R and cel48_920R were labelled with 6carboxyfluorescein (FAM). For each sample, nine PCR reactions were pooled together and purified with QIAquick gel extraction kit (Qiagen). The pooled amplicons of cel5 and cel48 were digested overnight at $37^{\circ} \mathrm{C}$ with restriction enzyme MboI (New England Biolabs, Wilbury Way Hitchin, Herts, UK) and AluI (Fermentas), respectively. Fluorescently labelled terminal restriction fragments (T-RFs) were separated and detected with ABI3730xl capillary sequencer (Applied
Biosystems, Cheshire, UK). GS ROX 500 internal size standard (Applied Biosystems) was included in all assays. T-RFLP profiles were processed by Peak Scanner software (Applied Biosystems). The relative abundance of the individual T-RFs was calculated by dividing the peak area by the total area of all peaks. T-RFs constituting less than $1 \%$ of the total peak area were excluded as background.

\section{qPCR}

To quantify the abundance of cel48, qPCR was performed using CFX96 real-time PCR detection system (Bio-Rad, Hercules, CA, USA). The PCR programme used was $10 \mathrm{~min}$ at $95^{\circ} \mathrm{C}$, followed by 55 cycles of $40 \mathrm{~s}$ at $95^{\circ} \mathrm{C}, 30 \mathrm{~s}$ at the annealing temperature of $56^{\circ} \mathrm{C}$, and $30 \mathrm{~s}$ at $72^{\circ} \mathrm{C}$. A standard curve was constructed with genomic DNA from Clostridium cellulolyticum (DSM 5812) for primer cel48, following the protocol described previously [26]. Each reaction contained $10 \mu \mathrm{L}$ of Maxima qPCR master mix with SYBR Green (Fermentas), $3 \mu \mathrm{L}$ of DNA template and $0.5 \mu \mathrm{M}$ of each primer with a final volume of $20 \mu \mathrm{L}$. Melt curve analysis and the qPCR data processing were conducted as described previously [26].

\section{Nucleotide accession numbers}

All sequences were deposited in the NCBI GenBank database. Clones obtained by primer pair cel48 can be identified by the accession numbers KC78964650 (OTU01), KC789651-58 (OTU02), KC78965964 (OTU03), KC789665-66 (OTU04), KC789667-69 (OTU05), KC789670 (OTU06), KC789671-73 (OT U07), KC789674-83 (OTU08), and KC789684 (OT U09). Clones obtained by primer pair cel5 can be identified by the accession numbers: KC789685-86 (OT U01), KC789687 (OTU02), KC789688-92 (OTU03), KC789693-97 (OTU04), KC789698-700 (OTU05), KC 789701-11 (OTU06), and KC789712 (OTU07), KF 193414-17 (OTU08).

\section{Results and discussion T-RFLP \\ Cel48}

The cellulose-degrading community structure in the different digesters, managed with different operating strategies and substrates, was examined by T-RFLP analysis combined with the construction of clone libraries. The T-RFLP profile obtained with primer cel48 (Figure 1a) was similar for digesters $\mathrm{RM}$ (with manure only, $37^{\circ} \mathrm{C}$ ) and RS (with manure and un-treated straw, $37^{\circ} \mathrm{C}$ ). The communities identified in both digesters were mainly represented by the T-RFs of 249,322 and $328 \mathrm{bp}$. The T-RF 328 bp dominated, with a relative abundance of $54.9 \%$ and $66.9 \%$ in RM and RS, respectively. The similar 


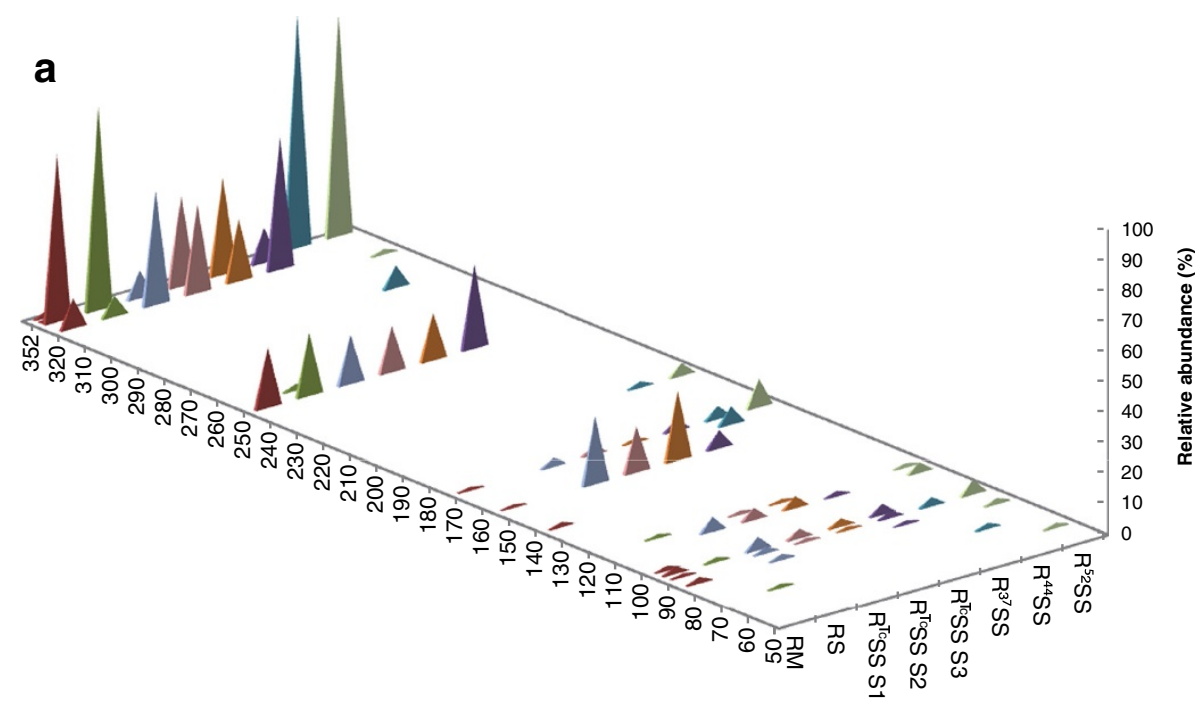

b

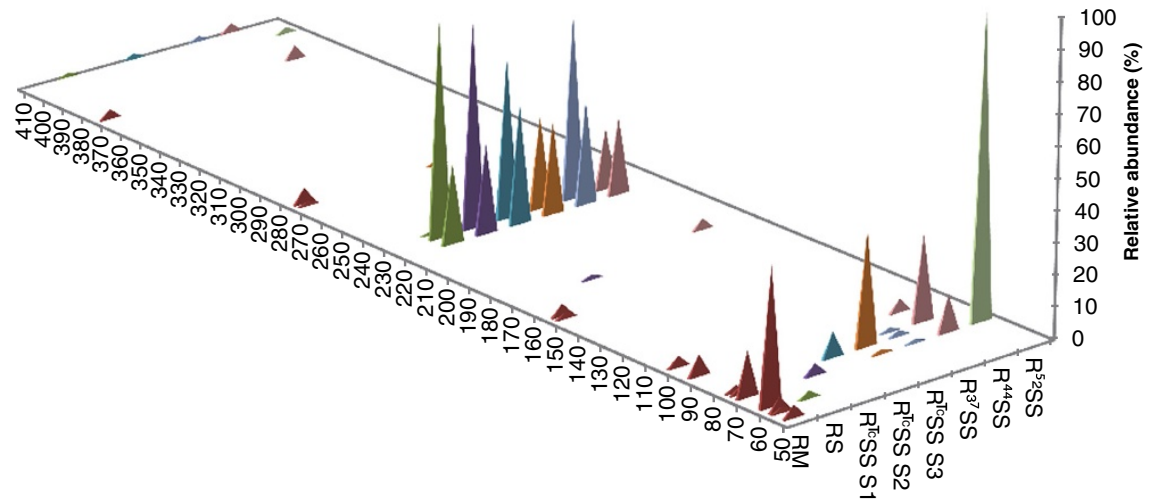

Figure 1 T-RFLP profile. T-RFLP profile representing the community of (a) glycoside hydrolases gene family 48 (cel48) and (b) glycoside hydrolases gene family 5 (cel5) in four lab-scale digesters processing: (1) manure (RM); (2) mechanically chopped (un-treated) straw and manure (RS); (3) steam-exploded straw and manure, operating temperatures $37^{\circ} \mathrm{C}, 44^{\circ} \mathrm{C}$ and $52^{\circ} \mathrm{C}\left(\mathrm{R}^{37} \mathrm{SS}, \mathrm{R}^{44} \mathrm{SS}\right.$ and $\mathrm{R}^{52} \mathrm{SS}$ ); and (4) steam-exploded straw and manure, operating constantly at $37^{\circ} \mathrm{C}\left(R^{\top} \mathrm{SS} S 1\right.$ to $\left.S 3\right)$, where $\mathrm{S} 1, \mathrm{~S} 2$ and $\mathrm{S} 3$ correspond to the same sampling point as $\mathrm{R}^{37} \mathrm{SS}, \mathrm{R}^{44} \mathrm{SS}$ and $\mathrm{R}^{52} \mathrm{SS}$.

T-RFLP profile observed in the digesters RM and RS suggests that straw did not have an impact on the community relative to manure alone. However, the community in digester $\mathrm{R}^{\mathrm{Tc}} \mathrm{SS}$ (manure with steam-explored straw, $37^{\circ} \mathrm{C}$ ) was slightly different to that in digesters $\mathrm{RM}$ and RS, suggesting that pre-treatment of the straw enabled new organisms to be active in degradation (Figure 1a). The T-RF at $322 \mathrm{bp}$ had a higher abundance in $\mathrm{R}^{\mathrm{Tc}} \mathrm{SS}(20.3 \%$ to $37.3 \%)$ than in $\mathrm{RM}(9.8 \%)$ and $\mathrm{RS}$ (6.7\%). Moreover, the community in $\mathrm{R}^{\mathrm{Tc}} \mathrm{SS}$ was also complemented with a new T-RF of 157 bp (14.8\% to $22.7 \%$ ). Analysis of samples from digester $\mathrm{R}^{\mathrm{Tc}} \mathrm{SS}$, at three different time points (days 89, 224 and 402) showed a similar pattern, illustrating the stability over time and strengthening the hypothesis that the observed difference between this digester and RM and RS was caused by pre-treatment of the straw. Digester $\mathrm{R}^{37} \mathrm{SS}$ started with the same operating parameters and substrate as digester $\mathrm{R}^{\mathrm{Tc}} \mathrm{SS}$, but was subjected to a temperature change. On day 89 , both $R^{37} S S$ and $R^{\text {Tc }} S S$ had the same operating conditions and here the T-RFLP profiles had the same patterns. However, after changing the temperature in $\mathrm{R}^{44} \mathrm{SS}$, there was an apparent shift in the community and a new fragment of 355 bp became most dominant, with a relative abundance of $76.2 \%$ (Figure 1a). In addition, two new T-RFs of $294 \mathrm{bp}$ (abundance $7.2 \%$ ) and 168 bp (5.9\%) appeared in the $\mathrm{R}^{44} \mathrm{SS}$ profile. None of these three T-RFs were detected in the reactors operating at $37^{\circ} \mathrm{C}$. On day 540 , a similar T-RFLP profile was observed in digester $\mathrm{R}^{52} \mathrm{SS}$ as in $\mathrm{R}^{44} \mathrm{SS}$, but the T-RFs at 168 and $294 \mathrm{bp}$ were absent. 


\section{Cel5}

In contrast to the results obtained using primer pair cel48, the T-RFLP profiles for cel5 were different in digesters RM and RS (Figure 1b). In RM the community was dominated by two T-RFs of $64 \mathrm{bp}$ (abundance $44.1 \%)$ and $74 \mathrm{bp}(14.5 \%)$. These T-RFs were not present in RS, and instead the community was dominated by T-RFs 222 bp (26.0\%) and 228 bp (69.1\%). The two digesters were run in similar conditions, with the chopped, non-steam-exploded wheat straw in digester RS being the only difference. Thus, the results suggest that the presence of additional straw affected the cel5 community structure. When comparing the T-RFLP profiles of RS, $\mathrm{R}^{\mathrm{Tc}} \mathrm{SS} \mathrm{S} 1$ and $\mathrm{R}^{37} \mathrm{SS}$, a similar pattern was observed, suggesting that the steam explosion of the straw had no effect on the cel5 community. This result is also in contradiction to the results obtained when analysing the cel48 community, which changed in response to pretreatment of the straw. However, the cel5 profile of $\mathrm{R}^{\mathrm{Tc}} \mathrm{SS}$ changed over time with an enrichment of T-RFs 81 bp $(8.2 \%$ abundance at S2 and $36.3 \%$ at S3) during operation. It is unclear if this change was caused by the steam-exploded straw or just time. This change in community did not have an effect on the digester performance (e.g. the gas yield) [25]. However, analysis of the methane potential in batch tests using inocula from the digesters, taken at the same time points as the samples for community analysis, illustrated different cellulosedegrading efficiency at the different time points, possibly explained by the community shift [25]. $\mathrm{R}^{\mathrm{Tc}} \mathrm{SS}$ and $\mathrm{R}^{37} \mathrm{SS}$ shared similar profiles at the first sampling point on day 89. However, on day 224, at the second sampling point at $44^{\circ} \mathrm{C}\left(\mathrm{R}^{44} \mathrm{SS}\right)$, the T-RFs $85,95,183$ and 380 bp emerged in the profile with a relative abundance of $27.5 \%, 4.2 \%, 3.5 \%$ and $4.7 \%$, respectively. None of these $\mathrm{T}$-RFs was present in $\mathrm{R}^{\mathrm{Tc}} \mathrm{SS}$, which ran at $37^{\circ} \mathrm{C}$ over the whole study period. T-RF $74 \mathrm{bp}$ also increased in response to the increase in temperature, with abundance of $11.8 \%$, compared to $3.8 \%$ and $1.5 \%$ at sampling points $\mathrm{R}^{\mathrm{Tc}} \mathrm{SS} \mathrm{S} 1$ and $\mathrm{S} 3$, respectively. At the third sampling point $\left(\mathrm{R}^{52} \mathrm{SS}\right)$, the T-RFLP was dominated by this T-RF of $74 \mathrm{bp}$, representing $98 \%$ of the relative abundance. In line with the T-RFLP of the cel48 community, this illustrates the impact of temperature on the cellulolytic community. Furthermore, it suggests a relatively low complexity of the cel5 community at thermophilic conditions, i.e. dominated by only one T-RF (Figure 1b).

\section{Clone libraries and phylogenetic analysis}

To identify the T-RFs in the T-RFLP analysis, clone libraries were constructed for digester $\mathrm{R}^{44} \mathrm{SS}$ with primer cel5 and for digesters $\mathrm{RM}, \mathrm{R}^{\mathrm{Tc}} \mathrm{SS}$ and $\mathrm{R}^{44} \mathrm{SS}$ with primer cel48. The sequence analysis recovered most of the T-RFs in the T-RFLP profiles from cel48 community
(Table 1). For cel5 one major peak (T-RFs $64 \mathrm{bp}$ ) was not identified in the RM sample. The phylogenetic relationship of the sequences obtained was investigated by comparing them to the database, followed by maximum likelihood tree construction (Table 1, Figures 2 and 3). In general, the degree of similarity to the characterised bacteria was low, and some clones were more closely related to uncultured bacteria. For cel48, all of the sequenced clones belonged to the class of Clostridia, within the Firmicutes; mainly two families, Clostridiaceae and Ruminococcaceae. Previous studies have reported the importance of the phylum Firmicutes for the hydrolysis of cellulosic materials in biogas digesters, particularly the class Clostridia [29-31]. The genus Ruminococcus commonly present in the rumen was also identified in the clone sequences obtained with primer cel48. This genus has previously also been found in anaerobic digesters [32]. For cel5, the clones obtained all belonged to the phyla Bacteroidetes and Firmicutes, which is in agreement with other studies on biogas reactors. By targeting $16 \mathrm{~S}$ rRNA genes, high abundance of representatives of both phyla have been found in biogas digesters operating with plant-based materials and/or manure, including a CSTR biogas digester fed

Table 1 Summarised clone sequences of cel5 and cel48

\begin{tabular}{|c|c|c|c|c|}
\hline Clone & $\begin{array}{c}\text { T- } \\
\text { RFs }\end{array}$ & $\begin{array}{l}\text { Most closely related } \\
\text { microorganism }\end{array}$ & $\begin{array}{c}\text { Identity } \\
(\%)\end{array}$ & $\begin{array}{l}\text { Accession } \\
\text { number }\end{array}$ \\
\hline \multicolumn{5}{|l|}{ Cel48 } \\
\hline OTU01 & 249 & Acetivibrio cellulolyticus & 69.5 & ZP_09463651 \\
\hline OTU02 $^{\mathrm{a}}$ & 328 & Clostridium josui & 72.9 & BAA32430 \\
\hline OTU03 & 322 & Clostridium straminisolvens & 79.0 & ACV92097 \\
\hline OTU04 & 168 & $\begin{array}{l}\text { Ruminococcus } \\
\text { champanellensis }\end{array}$ & 61.8 & CBL17316 \\
\hline OTU05 & 352 & Ruminococcus albus & 46.1 & YP_004105715 \\
\hline OTU06 & 157 & Ruminococcus flavefaciens & 68.7 & ZP_06145360 \\
\hline OTU07 & 294 & Acetivibrio cellulolyticus & 74.3 & ZP_09463651 \\
\hline OTU08 & 355 & Clostridium straminisolvens & 80.0 & ACV92097 \\
\hline OTU09 & 328 & Clostridium cellulolyticum & 100 & YP_002505088 \\
\hline \multicolumn{5}{|l|}{ Cel5 } \\
\hline OTU01 & 74 & Eubacterium siraeum & 49.5 & CBK96866 \\
\hline OTU02 & 173 & Flavobacterium johnsoniae & 65.7 & YP_001193127 \\
\hline OTU03 $^{\mathrm{b}}$ & 222 & Eubacterium cellulosolvens & 52.5 & ZP_10167476 \\
\hline OTU04 & 228 & Marinilabilia salmonicolor & 63.8 & ZP_11227339 \\
\hline OTU05 & 380 & Flavobacterium johnsoniae & 62.9 & YP_001193127 \\
\hline OTU06 $^{\mathrm{d}}$ & 85 & Mahella australiensis & 60.4 & YP_004463133 \\
\hline OTU07 & 380 & Flavobacterium johnsoniae & 62.9 & YP_001193127 \\
\hline OTU08 & 81 & Echinicola vietnamensis & 57.4 & YP_007223444 \\
\hline
\end{tabular}

${ }^{\mathrm{a}}$ More closely related to uncultured bacterium from sulphate-reducing reactors (identity $81.3 \%, \mathrm{ACV} 50351$ ); ${ }^{\mathrm{b}}$ More closely related to uncultured bacterium from buffalo rumen (identity $54.3 \%$, ACA61144) ${ }^{\mathrm{C}}$ More closely related to uncultured bacterium from human gut (identity 68.3\%, ADD61911); ${ }^{\mathrm{d}}$ More closely related to uncultured bacterium from biogas digester (identity 100\%, AEV59735). 
with fodder beet silage and cattle manure [30], a biogas digester processing pig manure [33] and a biogas reactor operating with maize silage, bruised grain, cattle manure and pig manure [34]. In the present study, representatives of the class Clostridia comprised $26.0 \%$ and $31.1 \%$ to $38.2 \%$ of the total cel5 community in digester RS and $\mathrm{R}^{\mathrm{Tc}} \mathrm{SS}$, respectively. Furthermore, the proportion increased in the digester subjected to a temperature rise, from $36 \%$ at $37^{\circ} \mathrm{C}\left(\mathrm{R}^{37} \mathrm{SS}\right)$ to $64.8 \%$ at $44^{\circ} \mathrm{C}\left(\mathrm{R}^{44} \mathrm{SS}\right)$ and $98.0 \%$ at $52^{\circ} \mathrm{C}\left(\mathrm{R}^{52} \mathrm{SS}\right)$. An increase in the abundance of Clostridia in response to temperature has been reported in previous studies on biogas digesters degrading a variety of different substrates $[19,35,36]$.

\section{Cel48}

The T-RF 249 bp represented by OTU01 was present in all samples from digesters running at $37^{\circ} \mathrm{C}$, comprising between $15.0 \%$ and $27.6 \%$ of the population. T-RF 294 bp (represented by OTU07) was present in digester $\mathrm{R}^{44} \mathrm{SS}\left(44^{\circ} \mathrm{C}\right)$ with a relative abundance of $7.2 \%$. These OTUs were related to Acetivibrio cellulolyticus (identities $69.5 \%$ and $74.3 \%$, respectively) isolated from municipal sewage sludge. This cellulolytic bacterium is able to grow on cellulose, cellobiose and salicin, but cannot metabolise simple sugars such as glucose, fructose or xylose. Acetic acid, hydrogen and carbon dioxide are formed as major fermentation products from cellulose or cellobiose. The optimal growth temperature range is $20^{\circ} \mathrm{C}$ to $40^{\circ} \mathrm{C}$, and no growth occurs at $43^{\circ} \mathrm{C}$ [37]. The presence of a species grouping with A. cellulolyticus in $\mathrm{RM}, \mathrm{RS}, \mathrm{R}^{\mathrm{Tc}} \mathrm{SS}$ and $\mathrm{R}^{37} \mathrm{SS}$ might suggest its importance during the degradation of cellulolytic material at mesophilic temperature $\left(37^{\circ} \mathrm{C}\right.$ to $\left.44^{\circ} \mathrm{C}\right)$. The T-RF 294 bp was only detected in $\mathrm{R}^{44} \mathrm{SS}$, indicating the possible existence of a thermo-tolerant mesophilic strain of this species. However, in line with the growth pattern of the characterised species, neither of the two T-RFs was detected in digester $\mathrm{R}^{52} \mathrm{SS}\left(52^{\circ} \mathrm{C}\right)$. Species of the genus Acetivibrio have previously been identified in biogas digesters, including a CSTR $\left(35^{\circ} \mathrm{C}\right)$ fed with fodder beet silage and cattle manure [30], a production-scale biogas plant $\left(41^{\circ} \mathrm{C}\right)$ fed with maize silage, green rye and chicken manure [38], and a biogas digester processing pig manure [33]. In the phylogenetic tree in this study

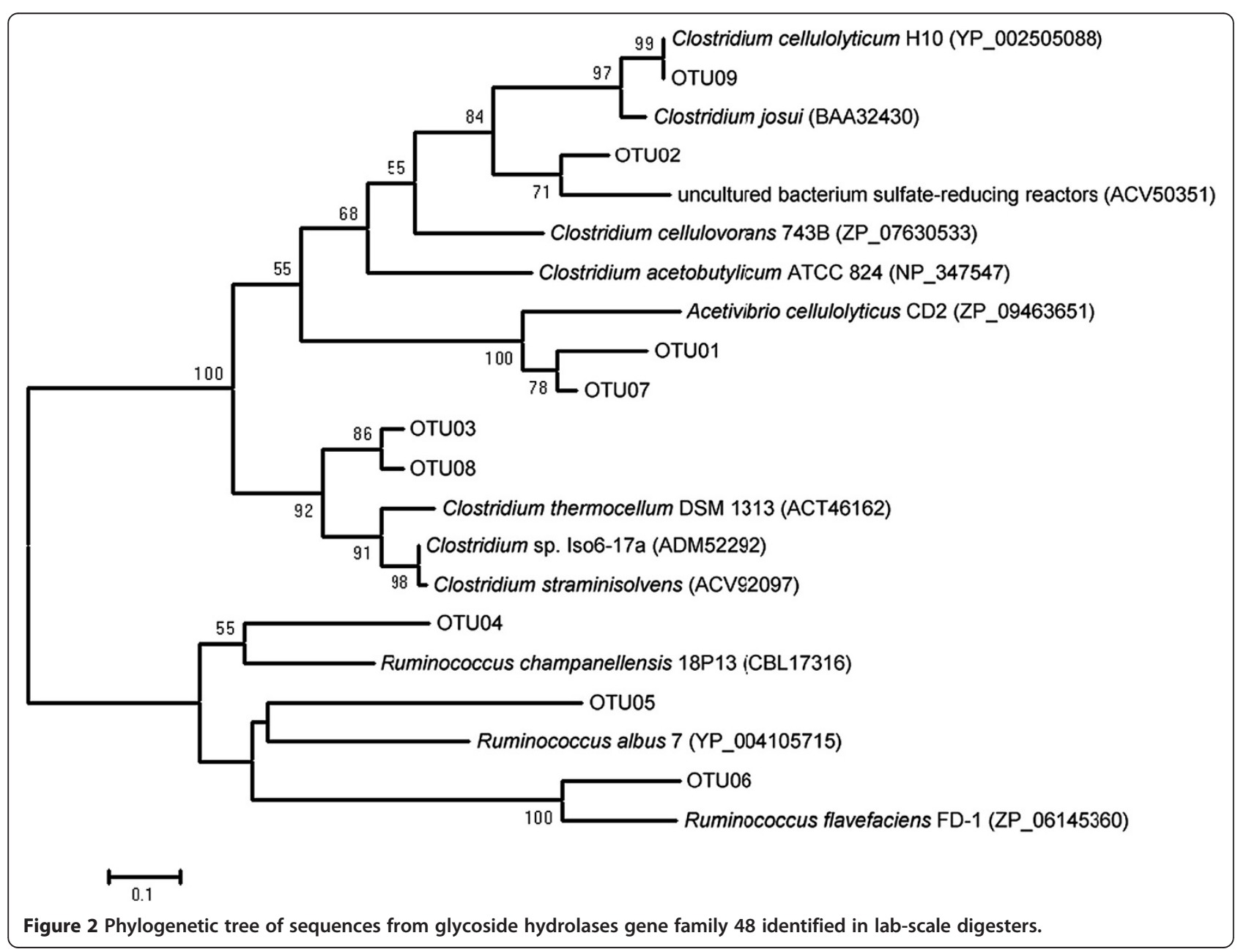




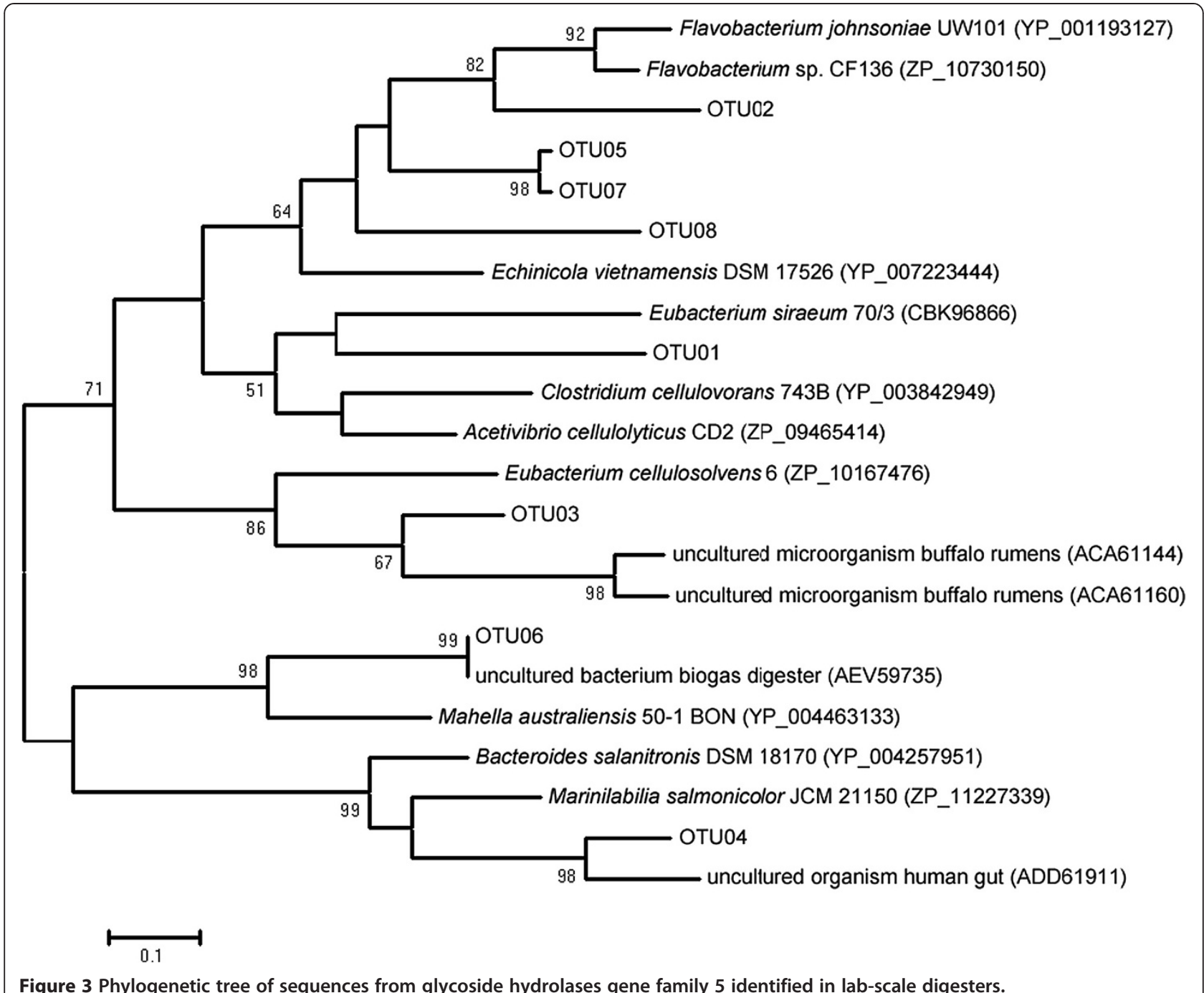

(Figure 2), OTU06, OTU04 and OTU05 grouped together with representatives of the genus Ruminococcus. T-RF 157 bp (OTU06) was detected in all the mesophilic digesters operating with steam-exploded straw $\left(\mathrm{R}^{\mathrm{Tc}} \mathrm{SS}\right.$ and $\mathrm{R}^{37} \mathrm{SS}$ ) and was grouped together with Ruminococcus flavefaciens (68.7\% identity). This bacterium was isolated from rumen fluid and can utilise both cellulose and cellobiose as substrates for growth [39]. The presence of such a species might suggest competitiveness specifically for the degradation of the steam-exploded wheat straw. T-RF 352 bp (OTU05), closely related to Ruminococcus albus (46.1\% identity), was only detected at $1 \%$ in digester RM. This bacterium has been isolated from rumen fluid and can utilise cellulose and cellobiose. R. flavefaciens is different from $R$. albus by producing succinate as the major fermentation product [40]. The T-RF 168 bp (OTU04) was only observed in the digester operating at $44^{\circ} \mathrm{C}\left(\mathrm{R}^{44} \mathrm{SS}\right)$. This clone was most closely related to Ruminococcus champanellensis (61.8\% identity), a cellulolytic bacterium isolated from human faeces that ferments cellulose, cellobiose and xylan, produces acetate and succinate as the main fermentation products and grows optimally from $33^{\circ} \mathrm{C}$ to $39^{\circ} \mathrm{C}$ (optimum $39^{\circ} \mathrm{C}$ ) [41]. In a previous study, the abundance of Ruminococcus in a biogas digester was shown to increase after pre-treatment of sludge from a wastewater plant [32]. A Ruminococcus sp.-like clone was also recovered in another biogas process operating with synthetic wastes under thermophilic conditions [42]. Clones with T-RFs 322 and 355 bp (OTU03 and 08) were closely related to Clostridium straminisolvens, with an identity of $79.0 \%$ and $80.0 \%$ respectively. The former was observed in all the mesophilic digesters, while the latter was only found in $\mathrm{R}^{44} \mathrm{SS}$ and $\mathrm{R}^{52} \mathrm{SS}$. The type strain $\mathrm{CSK} 1^{\mathrm{T}}$ of $C$. straminisolvens was isolated from an enrichment originating from an artificial compost process [43]. When using cellulose as the sole carbon and energy source, the optimum growth temperature has been shown to be $50^{\circ} \mathrm{C}$ to $55^{\circ} \mathrm{C}$, with no growth below $45^{\circ} \mathrm{C}$, and acetate, lactate, ethanol, hydrogen and carbon 


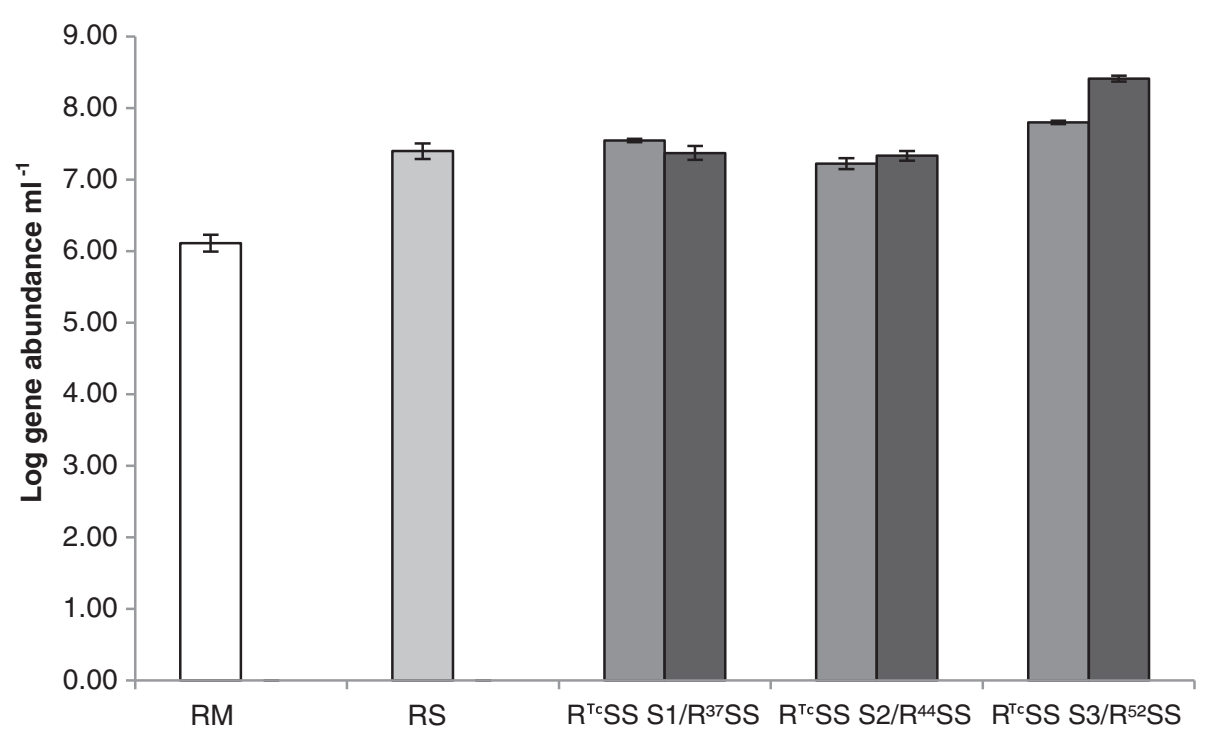

Figure 4 Real-time PCR analysis of the abundance of glycoside hydrolases gene of family $\mathbf{4 8}$ (cel48). Real-time PCR analysis of the abundance of glycoside hydrolases gene of family 48 (cel48) in four laboratory-scale digesters processing: (1) manure (RM); (2) mechanically chopped (un-treated) straw and manure (RS); (3) steam-exploded straw and manure, operating temperature $37^{\circ} \mathrm{C}, 44^{\circ} \mathrm{C}$ and $52^{\circ} \mathrm{C}\left(\mathrm{R}^{37} \mathrm{SS}, \mathrm{R}^{44} \mathrm{SS}\right.$ and $\mathrm{R}^{52} \mathrm{SS}$ ); and (4) steam-exploded straw and manure, operating constantly at $37^{\circ} \mathrm{C}\left(\mathrm{R}^{\mathrm{T} C} \mathrm{SS} S 1\right.$ to $\mathrm{S} 3$ ), where $\mathrm{S} 1, \mathrm{~S} 2$ and $\mathrm{S} 3$ correspond to the same sampling point as $\mathrm{R}^{37} S S, \mathrm{R}^{44} S S$ and $\mathrm{R}^{52} \mathrm{SS}$.

dioxide as the main fermentation products [43]. The common presence of bacteria related to C. straminisolvens in the digesters investigated here suggests both an important role in degradation and the possible existence of uncultured mesophilic strains. The T-RF 328 bp, representing OTU02 and OTU09, was detected in all mesophilic digesters (RM, $\mathrm{RS}, \mathrm{R}^{\mathrm{Tc}} \mathrm{SS}$ and $\mathrm{R}^{37} \mathrm{SS}$ ), with a higher abundance in digesters RM (54.9\%) and RS (66.9\%). OTU02 was most closely related to an uncultured clone sequence (identity $81.3 \%$ ) from mine drainage treatment systems with a high content of lignocellulosic carbon source [24]. The most closely related characterised bacterium is Clostridium josui isolated from compost and capable of fermenting various substrates such as cellulose, cellobiose, arabinose, glucose, maltose, ribose, xylose and xylan at temperatures between $25^{\circ} \mathrm{C}$ and $60^{\circ} \mathrm{C}$ [44]. OTU09 is identical to a characterised bacterium $C$. cellulolyticum, isolated from decayed grass, which can grow on cellulose, arabinose, cellobiose, fructose, glucose and $x y-$ lose within the temperature range $25^{\circ} \mathrm{C}$ to $45^{\circ} \mathrm{C}$.

\section{Cel5}

By analysing the cloned sequences generated from primer set cel5, two T-RFs of 222 and 228 bp (OTU03 and 04 ) were abundant in digesters receiving straw at $37^{\circ} \mathrm{C}\left(\mathrm{RS}, \mathrm{R}^{\mathrm{Tc}} \mathrm{SS}\right.$ and $\mathrm{R}^{37} \mathrm{SS}$ ) and $44^{\circ} \mathrm{C}\left(\mathrm{R}^{44} \mathrm{SS}\right)$. OTU03 grouped together with an uncultured microorganism from rumen (Figure 3) with an identity of 54.3\% [45]. The most closely related characterised strain is Eubacterium cellulosolvens [46] isolated from rumen, which is capable of fermenting cellulose and cellobiose as well as several monomeric sugars. OTU04 is similar (identity $68.3 \%$ ) to a cellulolytic uncultured microorganism from the human gut [47]. The most closely related characterised bacterium is Marinilabilia salmonicolor, which is capable of fermenting various substrates such as cellulose, cellobiose, different monomeric sugars, inulin and starch $[48,49]$. T-RF 85 bp (OTU06) is closely related to an uncultured bacterium (identity $100 \%$, AEV59735) detected in a biogas digester, but, unfortunately, information on this digester has not yet been published. The closest known relative is Mahella australiensis (identity 60.4\%) isolated from an oil reservoir, which can ferment arabinose, cellobiose, fructose, galactose, glucose, sucrose, xylose and pyruvate [50]. TRF 173 bp (OTU02) is similar to Flavobacterium johnsoniae (identity 65.7\%) commonly present in soil and freshwater [51]. Recently, genome analysis predicted numerous glycoside hydrolases and esterases, suggesting the capability for hemicellulose utilisation [52]. Clones with a T-RF of $380 \mathrm{bp}$ (representing OTU05 and 07) were rather distantly related to $F$. johnsoniae. A clone with T-RF 74 bp was close to Eubacterium siraeum (49.5\% identity) isolated from human faeces [53]. The TRF $81 \mathrm{bp}$, enriched over time in the $\mathrm{R}^{\mathrm{Tc}} \mathrm{SS}$, was most closely related to Echinicola vietnamensis (57.4\% identity) isolated from seawater [54] but has also high similarity to Cellvibrio japonicus isolated from soil [55]. The former is a gliding bacterium degrading starch, but not cellulose, cellobiose or glucose and with optimal growth temperature ranges from $30^{\circ} \mathrm{C}$ to $32^{\circ} \mathrm{C}$. The latter is 


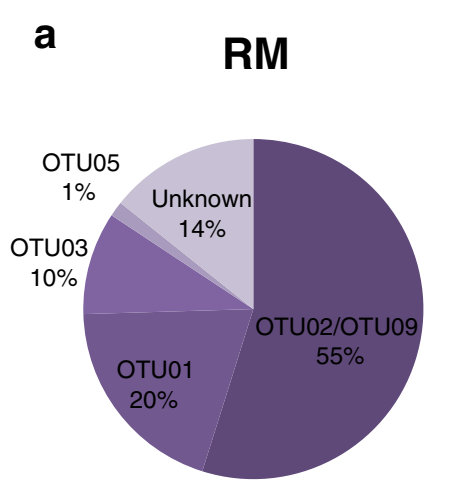

$\mathbf{R}^{\text {Tc }} \mathbf{S S ~ S 3}$

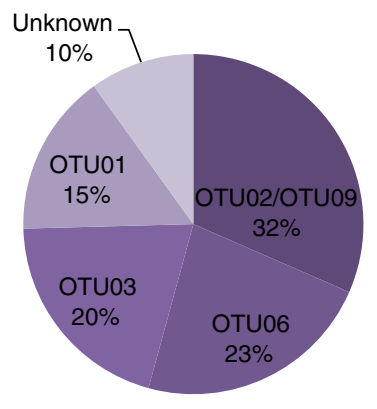

b
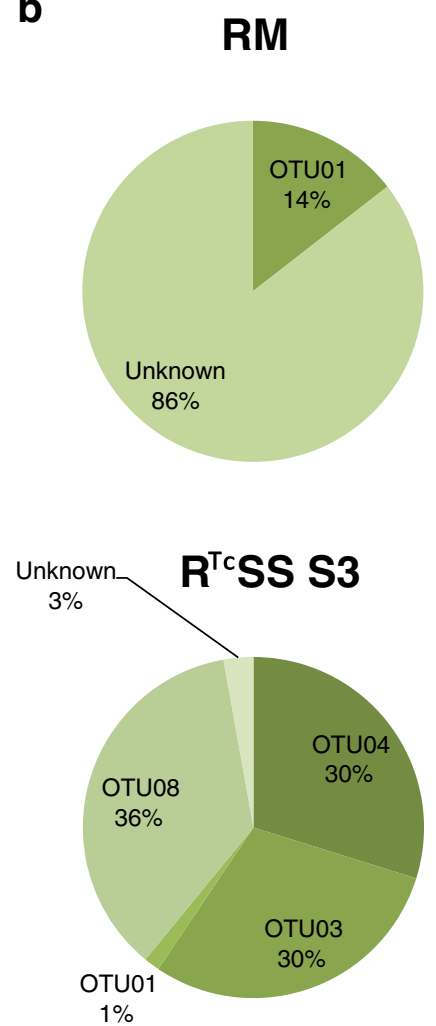

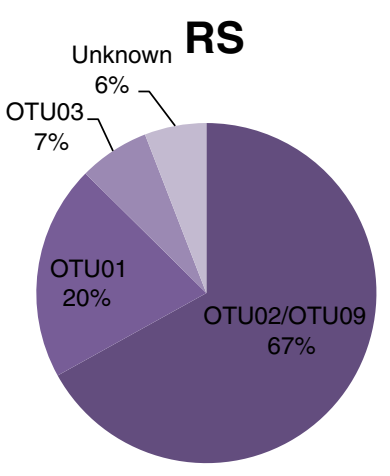

$R^{52} S S$
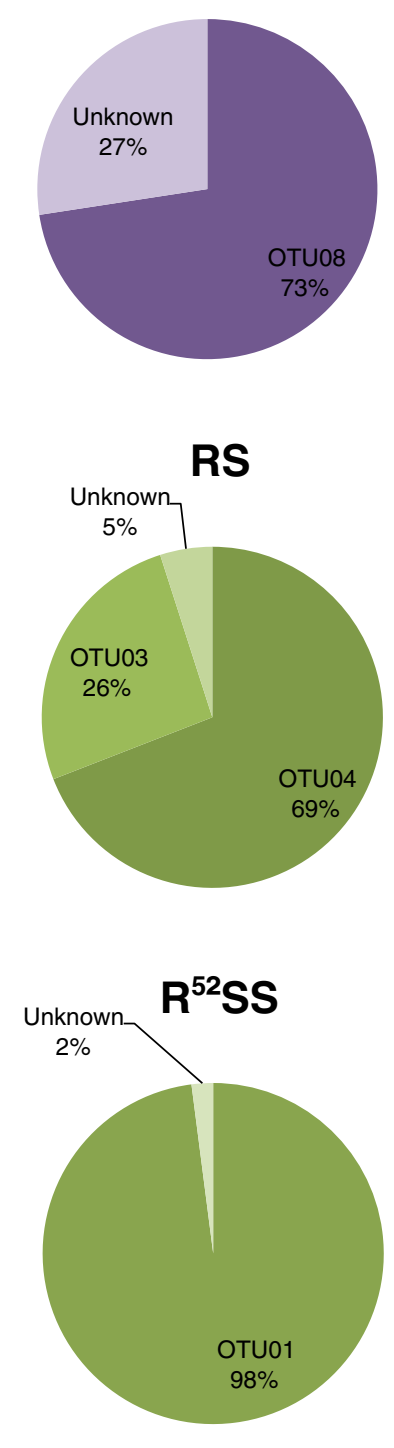

Figure 5 Summarised relative abundance of each OTU based on the T-RFLP profiles. (a) cel48 and (b) cel5 in four laboratory-scale digesters processing: (1) manure (RM); (2) mechanically chopped (un-treated) straw and manure (RS); (3) steam exploded straw and manure, operating at temperature $37^{\circ} \mathrm{C}\left(\mathrm{R}^{37} \mathrm{SS} S 3\right)$; and (4) steam-exploded straw and manure, operating at $52^{\circ} \mathrm{C}\left(\mathrm{R}^{52} \mathrm{SS}\right)$. 
considered as a specialist for plant degradation harbouring a lot of different kinds of glycoside hydrolases [54,55]. This T-RF had a relative abundance of $8.2 \%$ and $36.3 \%$ at the last two sampling occasions (Figure 1b).

It is worth noting that the clone library of cel5 revealed that this primer set picked up a large proportion of a non-specific sequence of $483 \mathrm{bp}$ ( 29 out of 91 clones sequenced). Thus this primer pair was not used for qPCR assay and the T-RF of $436 \mathrm{bp}$ derived from the amplicon 483 bp was excluded from the T-RFLP results.

\section{qPCR}

The glycoside hydrolase family 48 gene (cel48) was quantified in all lab-scale digesters using qPCR (Figure 4), with a reaction efficiency varying between $97.2 \%$ and $98.3 \%$, while the linear correlation coefficient $r^{2}$ was between 0.977 and 0.992 . The abundance of cel48 in digester RM was $1.3 \pm 0.3 \times 10^{6}$ copies $/ \mathrm{mL}$. The digesters with straw (treated and un-treated) had a tenfold increase in copy number; RS $\left(2.5 \pm 0.6 \times 10^{7}\right.$ copies $\left./ \mathrm{mL}\right)$, $\mathrm{R}^{\mathrm{Tc}} \mathrm{SS}\left(1.7 \pm 0.3 \times 10^{7}\right.$ to $6.3 \pm 0.3 \times 10^{7}$ copies $\left./ \mathrm{mL}\right)$ and

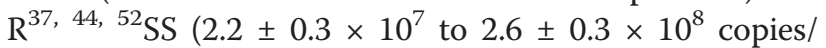
$\mathrm{mL})$. The abundances of cel48 were apparently relatively stable at all three sampling points in both $\mathrm{R}^{\mathrm{Tc}} \mathrm{SS}$ and $\mathrm{R}^{37,44,52} \mathrm{SS}$, and thus the temperature did not have any significant effect on cel48 abundance.

\section{Conclusions}

In summary, the quantitative information on the abundance of cel48 obtained by qPCR assay revealed that straw in the substrate stimulated a tenfold increase in the numbers of this gene copy. Community analysis by T-RFLP combined with construction of clone libraries showed that complementing manure with non-treated straw for co-digestion clearly changed the cel5 community (Figure 5b), while the cel48 community remained approximately the same, irrespective of straw addition. On the other hand, pre-treatment of the straw by steam explosion initially had an impact on the cel48 community only (Figure 5a). However, the profile in the cel5 community in the digester operating with steamexploded straw changed over time and became separated from the digester operating with un-treated straw (Figure 5b). Both communities responded to the increase in operating temperature, e.g. new sequence types appeared and the complexity of the population decreased, resulting in one or two dominant sequence types (Figure 5). Furthermore, many sequenced clones were more similar to sequences from uncultured organisms, particularly in the cel5 community, reflecting the demand of isolation and characterization of new species. In spite of the changes in the cellulose-degrading community structure, there was no major difference in the biogas yield of the digesters studied.

\section{Abbreviations}

AD: anaerobic digestion; Cel5: glycoside hydrolase families 5; Cel48: glycoside hydrolase families 48; HRT: hydraulic retention time; OTU: operational taxonomic unit; PCR: polymerase chain reaction; T-RF: terminal restriction fragment; T-RFLP: terminal restriction fragment length polymorphism; VS: Volatile solids.

\section{Competing interests}

The authors declare that they have no competing interests.

\section{Authors' contributions}

LS carried out the laboratory work, participated in the planning of the study as well as analysis of the obtained data and was main responsible for writing the manuscript. BM provided analytical assistance, participating in planning of the study and in writing the manuscript. AS designed, conceived and coordinated the study and participated in analysis of data and in writing the manuscript. All authors read and approved the final manuscript.

\section{Acknowledgements}

The authors thank Ingvar Sundh, Kajsa Risberg and Jan Moestedt for valuable comments on the manuscript. We also acknowledge MicroDrive (http:// www.slu.se/microdrive) and The Swedish Energy Agency for the financial support. This work was also funded in part by the Research Council of Norway, grant numbers 190877/S60 and 203402/E20.

Received: 24 June 2013 Accepted: 25 June 2013

Published: 23 July 2013

\section{References}

1. Weiland P (2010) Biogas production: current state and perspectives. Appl Microbiol Biotechnol 85:849-860

2. EREC (2008) Renewable energy technology roadmap 20\% by 2020. European Renewable Energy Council, Brussels

3. Tsavkelova EA, Netrusov Al (2012) Biogas production from cellulosecontaining substrates: a review. Appl Biochem Microbiol 48:421-433

4. Appels L, Lauwers J, Degrève J, Helsen L, Lievens B, Willems K, van Impe J, Dewil R (2011) Anaerobic digestion in global bio-energy production: potential and research challenges. Renew and Sust Energ Rev 15:4295-4301

5. Wang G, Gavala HN, Skiadas IV, Ahring BK (2009) Wet explosion of wheat straw and codigestion with swine manure: effect on the methane productivity. Waste Manag 29:2830-2835

6. Monlau F, Barakat A, Trably E, Dumas C, Steyer J-P, Carrere C (2011) Lignocellulosic materials into biohydrogen and biomethane: impact of structural features and pretreatment. Crit Rev Environ Sci Technol 43:260-322

7. Taherzadeh MJ, Karimi K (2008) Pretreatment of lignocellulosic wastes to improve ethanol and biogas production: a review. Int J Mol Sci 9:1621-1651

8. Wang H, Tolvanen K, Lehtomäki A, Puhakka J, Rintala J (2010) Microbial community structure in anaerobic co-digestion of grass silage and cow manure in a laboratory continuously stirred tank reactor. Biodegradation 21:135-146

9. Lehtomäki A, Huttunen S, Rintala JA (2007) Laboratory investigations on codigestion of energy crops and crop residues with cow manure for methane production: effect of crop to manure ratio. Resour, Conserv and Recy 51:591-609

10. Mshandete A, Kivaisi A, Rubindamayugi M, Mattiasson B (2004) Anaerobic batch co-digestion of sisal pulp and fish wastes. Bioresour Technol 95:19-24

11. Wu X, Yao W, Zhu J, Miller C (2010) Biogas and $\mathrm{CH}_{4}$ productivity by codigesting swine manure with three crop residues as an external carbon source. Bioresour Technol 101:4042-4047

12. Angelidaki I, Karakashev D, Batstone DJ, Plugge CM, Stams AJM (2011) Chapter sixteen - biomethanation and its potential. In: Rosenzweig AC, Ragsdale SW (eds) Methods in Methane Metabolism, Part A. Methods Enzymol, vol 494., pp 327-351

13. Lynd LR, Weimer PJ, van Zyl WH, Pretorius IS (2002) Microbial cellulose utilization: fundamentals and biotechnology. Microbiol Mol Biol Rev 66:506-577

14. Noike T, Endo G, Chang J-E, Yaguchi J-I, Matsumoto J-I (1985) Characteristics of carbohydrate degradation and the rate-limiting step in anaerobic digestion. Biotechnol Bioeng 27:1482-1489 
15. Ransom-Jones E, Jones D, McCarthy A, McDonald J (2012) The Fibrobacteres: an important phylum of cellulose-degrading bacteria. Microb Ecol 63:267-281

16. Morrison M, Pope PB, Denman SE, McSweeney CS (2009) Plant biomass degradation by gut microbiomes: more of the same or something new? Curr Opin Biotechnol 20:358-363

17. Merlino G, Rizzi A, Villa F, Sorlini C, Brambilla M, Navarotto P, Bertazzoni B, Zagni M, Araldi F, Daffonchio D (2012) Shifts of microbial community structure during anaerobic digestion of agro-industrial energetic crops and food industry byproducts. J Chem Technol Biotechnol 87:1302-1311

18. Yan L, Gao Y, Wang Y, Liu Q, Sun Z, Fu B, Wen X, Cui Z, Wang W (2012) Diversity of a mesophilic lignocellulolytic microbial consortium which is useful for enhancement of biogas production. Bioresour Technol 111:49-54

19. Lü Y, Li N, Gong D, Wang X, Cui Z (2012) The effect of temperature on the structure and function of a cellulose-degrading microbial community. Appl Biochem Biotechnol 168:219-233

20. van der Lelie D, Taghavi S, McCorkle SM, Li L-L, Malfatti SA, Monteleone D, Donohoe BS, Shi-You D, Adney WS, Himmel ME, Tringe SG (2012) The metagenome of an anaerobic microbial community decomposing poplar wood chips. PLoS One 7:e36740

21. Schwarz W (2001) The cellulosome and cellulose degradation by anaerobic bacteria. Appl Microbiol Biotechnol 56:634-649

22. Henrissat B (1991) A classification of glycosyl hydrolases based on amino acid sequence similarities. Biochem J 280(Pt 2):309-316

23. Henrissat B, Bairoch A (1996) Updating the sequence-based classification of glycosyl hydrolases. Biochem J 316(Pt 2):695-696

24. Pereyra LP, Hiibel SR, Prieto Riquelme MV, Reardon KF, Pruden A (2010) Detection and quantification of functional genes of cellulose-degrading, fermentative, and sulfate-reducing bacteria and methanogenic Archaea. Appl Environ Microbiol 76:2192-2202

25. Risberg K, Sun L, Leven L, Schnürer A (2013) Co-digestion of manure and steam exploded straw - process performance and yields. submitted

26. Westerholm M, Dolfing J, Sherry A, Gray ND, Head IM, Schnürer A (2011) Quantification of syntrophic acetate-oxidizing microbial communities in biogas processes. Environ Microbiol Rep 3:500-505

27. Edgar RC (2004) MUSCLE: multiple sequence alignment with high accuracy and high throughput. Nucleic Acids Res 32:1792-1797

28. Tamura K, Peterson D, Peterson N, Stecher G, Nei M, Kumar S (2011) MEGA5: Molecular evolutionary genetics analysis using maximum likelihood, evolutionary distance, and maximum parsimony methods. Mol Biol Evol 28:2731-2739

29. Wang H, Lehtomäki A, Tolvanen K, Puhakka J, Rintala J (2009) Impact of crop species on bacterial community structure during anaerobic codigestion of crops and cow manure. Bioresour Technol 100:2311-2315

30. Klocke M, Mähnert P, Mundt K, Souidi K, Linke B (2007) Microbial community analysis of a biogas-producing completely stirred tank reactor fed continuously with fodder beet silage as mono-substrate. Syst Appl Microbiol 30:139-151

31. Krause L, Diaz NN, Edwards RA, Gartemann K-H, Krömeke H, Neuweger H, Pühler A, Runte KJ, Schlüter A, Stoye J, Szczepanowski R, Tauch A, Goesmann A (2008) Taxonomic composition and gene content of a methane-producing microbial community isolated from a biogas reactor. J Biotechnol 136:91-101

32. Zhang H, Banaszak JE, Parameswaran P, Alder J, Krajmalnik-Brown $\mathrm{R}$, Rittmann BE (2009) Focused-pulsed sludge pre-treatment increases the bacterial diversity and relative abundance of acetoclastic methanogens in a full-scale anaerobic digester. Water Res 43:4517-4526

33. Liu FH, Wang SB, Zhang JS, Zhang J, Yan X, Zhou HK, Zhao GP, Zhou ZH (2009) The structure of the bacterial and archaeal community in a biogas digester as revealed by denaturing gradient gel electrophoresis and 165 rDNA sequencing analysis. J Appl Microbiol 106:952-966

34. Kampmann K, Ratering S, Kramer I, Schmidt M, Zerr W, Zerr W, Schnell S (2012) Unexpected stability of Bacteroidetes and Firmicutes communities in laboratory biogas reactors fed with different defined substrates. Appl Environ Microbiol 78:2106-2119

35. Levén L, Eriksson ARB, Schnürer A (2007) Effect of process temperature on bacterial and archaeal communities in two methanogenic bioreactors treating organic household waste. FEMS Microbiol Ecol 59:683-693

36. Lee SH, Kang HJ, Lee YH, Lee TJ, Han K, Choi Y, Park HD (2012) Monitoring bacterial community structure and variability in time scale in full-scale anaerobic digesters. J Environ Monit 14:1893-1905

37. Patel GB, Khan AW, Agnew BJ, Colvin JR (1980) Isolation and characterization of an anaerobic, cellulolytic microorganism, Acetivibrio cellulolyticus gen. nov., sp. nov. Int J Syst Bacteriol 30:179-185
38. Jaenicke $S$, Ander C, Bekel T, Bisdorf R, Dröge M, Gartemann KH, Jünemann S, Kaiser O, Krause L, Tille F, Zakrzewski M, Pühler A, Schlüter A, Goesmann A (2011) Comparative and joint analysis of two metagenomic datasets from a biogas fermenter obtained by 454-pyrosequencing. PLoS One 6:e14519

39. Sijpesteijn AK (1951) On Ruminococcus flavefaciens, a cellulose-decomposing bacterium from the rumen of sheep and cattle. J Gen Microbiol 5:869-879

40. Krause DO, Dalrymple BP, Smith WJ, Mackie Rl, McSweeney CS (1999) 165 rDNA sequencing of Ruminococcus albus and Ruminococcus flavefaciens: design of a signature probe and its application in adult sheep. Microbiology 145:1797-1807

41. Chassard C, Delmas E, Robert C, Lawson PA, Bernalier-Donadille A (2012) Ruminococcus champanellensis sp. nov., a cellulose-degrading bacterium from human gut microbiota. Int I Syst Evol Microbiol 62:138-143

42. Yang Y, Tsukahara K, Sawayama S (2008) Biodegradation and methane production from glycerol-containing synthetic wastes with fixed-bed bioreactor under mesophilic and thermophilic anaerobic conditions. Process Biochem 43:362-367

43. Kato S, Haruta S, Cui ZJ, Ishii M, Yokota A, Igarashi Y (2004) Clostridium straminisolvens Sp. nov., a moderately thermophilic, aerotolerant and cellulolytic bacterium isolated from a cellulose-degrading bacterial community. Int J Syst Evol Microbiol 54:2043-2047

44. Sukhumavasi J, Ohmiya K, Shimizu S, Ueno K (1988) Clostridium josui sp. nov., a cellulolytic, moderate thermophilic species from Thai compost. Int $J$ Syst Bacteriol 38:179-182

45. Duan C, Xian L, Zhao GC, Feng Y, Pang H, Bai XL, Tang JL, Ma QS, Feng JX (2009) Isolation and partial characterization of novel genes encoding acidic cellulases from metagenomes of buffalo rumens. J Appl Microbiol 107:245-256

46. Van Gylswyk NO, Hoffman JPL (1970) Characteristics of cellulolytic cillobacteria from the rumens of sheep fed teff (Eragrostis tef) hay diets. J Gen Microbiol 60:381-386

47. Tasse L, Bercovici J, Pizzut-Serin S, Robe P, Tap J, Klopp C, Cantarel BL, Coutinho PM, Henrissat B, Leclerc M, Doré J, Monsan P, Remaud-Simeon M, PotockiVeronese $\mathrm{G}$ (2010) Functional metagenomics to mine the human gut microbiome for dietary fiber catabolic enzymes. Genome Res 20:1605-1612

48. Nakagawa Y, Yamasato K (1996) Emendation of the genus Cytophaga and transfer of Cytophaga agarovorans and Cytophaga salmonicolor to Marinilabilia gen. nov: phylogenetic analysis of the FlavobacteriumCytophaga complex. Int J Syst Bacteriol 46:599-603

49. Suzuki M, Nakagawa Y, Harayama S, Yamamoto S (1999) Phylogenetic analysis of genus Marinilabilia and related bacteria based on the amino acid sequences of GyrB and emended description of Marinilabilia salmonicolor with Marinilabilia agarovorans as its subjective synonym. Int J Syst Evol Microbiol 49:1551-1557

50. Bonilla Salinas M, Fardeau M-L, Thomas P, Cayol J-L, Patel BKC, Ollivier B (2004) Mahella australiensis gen. nov., sp. nov., a moderately thermophilic anaerobic bacterium isolated from an Australian oil well. Int I Syst Evol Microbiol 54:2169-2173

51. Bernardet J-F, Segers P, Vancanneyt M, Berthe F, Kersters K, Vandamme P (1996) Cutting a gordian knot: emended classification and description of the genus Flavobacterium, emended description of the family Flavobacteriaceae, and proposal of Flavobacterium hydatis nom. nov. (basonym, Cytophaga aquatilis Strohl and Tait 1978). Int J Syst Bacteriol 46:128-148

52. McBride MJ, Xie G, Martens EC, Lapidus A, Henrissat B, Rhodes RG, Goltsman E, Wang W, Xu J, Hunnicutt DW, Staroscik AM, Hoover TR, Cheng YQ, Stein $J L$ (2009) Novel features of the polysaccharide-digesting gliding bacterium Flavobacterium johnsoniae as revealed by genome sequence analysis. Appl Environ Microbiol 75:6864-6875

53. Dabek M, McCrae SI, Stevens VJ, Duncan SH, Louis P (2008) Distribution of $\beta$-glucosidase and $\beta$-glucuronidase activity and of $\beta$-glucuronidase gene gus in human colonic bacteria. FEMS Microbiology Ecol 66:487-495

54. Nedashkovskaya OI, Bum Kim S, Hoste B, Shin DS, Belenava IA, Vancanneyt M, Mikhailov W (2007) Echinicola vietnamensis sp. nov., a member of the phylum Bacteroidetes isolated from seawater. Int I Syst Evol Microbiol 57:761-763

55. Humphry DR, Black GW, Cummings SP (2003) Reclassification of 'Pseudomonas fluorescens subsp. cellulosa' NCIMB 10462 (Ueda et al. 1952) as Cellvibrio japonicus sp. nov. and revival of Cellvibrio vulgaris sp. nov., nom. rev. and Cellvibrio fulvus sp. nov., nom. rev. Int I Syst Evol Microbiol 53 (2):393-400

doi:10.1186/2192-0567-3-15

Cite this article as: Sun et al:: Biogas production from wheat straw: community structure of cellulose-degrading bacteria. Energy, Sustainability and Society 2013 3:15. 